\title{
Rain Protective Covering of Sweet Cherry Trees-Effects of Different Covering Methods on Fruit Quality and Microclimate
}

\author{
J. Børve, ${ }^{1}$ E. Skaar, ${ }^{2}$ L. Sekse, ${ }^{3}$ \\ M. Meland, ${ }^{3}$ and E. Vangdal ${ }^{3}$
}

Additional index words. Prunus avium, protected cultivation, fruit cracking, fruit decay

Summary. Three different rain protective covering methods for sweet cherry (Prunus avium) trees were tested with uncovered trees as control. The covers were a pitched cover mounted permanently, a similar cover mounted only when raining, and a permanent umbrella type enveloping the top and sides of single trees. Covers were mounted 3 weeks before and throughout the harvest period in two seasons with different weather conditions. All three covering methods increased the amount of marketable fruit from 54\% on uncovered to $89 \%$ on covered trees in mean of 2 years. Fruit from umbrella covered trees had lower soluble solid content, lower juice color and lower ripeness compared with fruit from all other trees, reflecting the different microclimate in these trees such as frequently higher maximum temperatures and greater vapor pressure. The two pitched covers produced no significant changes in microclimate or internal fruit quality compared with uncovered trees.

This experiment was the basis for a MS thesis at Norwegian Agricultural University, and the first au thor is indebted to the advisor, Sigbjørn Vestrheim. We also thank A. Stensvand for critical review of the manuscript and Geir Olav Guddal for drawing the different covering methods.

${ }^{1}$ Research scientist and corresponding author (jorunn.borve@planteforsk.no), Norwegian Crop Research Institute, Ullensvang Research Centre, 5781 Lofthus, Norway.

${ }^{2}$ Research scientist, Norwegian Crop Research Institute, Geophysical Institute, Allegaten 70, 5007 Bergen, Norway.

${ }^{3}$ Head of department, Research scientist and Research scientist, Norwegian Crop Research Institute, Ullensvang Research Centre, 5781 Lofthus, Norway. 
S weet cherries are grown under different climatic conditions around the world. A common problem in cherry production is fruit cracking due to rain during the ripening period (Vittrup Christensen, 1996). Rain protective covering is an effective method to avoid fruit cracking in climates with frequent precipitation. Trials with rain protective covering of sweet cherry trees have been reported from several countries, e.g., England (Cline and Webster, 1994), Germany (Neidhart, 1980), Israel (Zilkah et al., 1997), New Zealand (Trought et al., 1994), Norway (Cline et al., 1995), Switzerland (Meli, 1982), and U.S. (Opperman 1988a, 1988b). Some of these results are variable and poorly explained, in particular how changes in microclimate caused by covers affect fruit quality.

This paper reports results from trials to reduce fruit cracking with rain protective covering 3 weeks before ripening. Three different covering methods were tested to examine their effects on percent marketable yield, fruit quality factors and microclimate in the trees. The results were partially presented in Børve and Meland (1998a, 1998b).

\section{Materials and methods}

Plant material and experimenTAL DESIGN. The experimental design was a complete randomized block trial with four blocks and four treatments located at Ullensvang Research Centre, western Norway at lat. $60^{\circ} \mathrm{N}$. The field slope was about $30^{\circ}$ towards west. Blocking was made by the field slope. Soil type was loamy sand high in organic matter. 'Van' trees grafted on 'Colt' rootstock and planted in 1991 were used. Trees planted at spacing 2 $\times 4 \mathrm{~m}(6.6 \times 13.1 \mathrm{ft})$ and trained as vertical axis kept at $3 \mathrm{~m}(9.8 \mathrm{ft})$ height made out the experimental material. The experiment was carried out during the 1994 and 1995 seasons. The orchard was managed according to standard procedures with fertilizers, drip irrigation, weed free strip in the tree row and plant protection program (three to four fungicide sprays). Each replicate consisted of three trees of which the samples were taken from the middle tree.

The covering methods were 1) permanently mounted pitched covers $[0.4 \mathrm{~m}(1.3 \mathrm{ft})]$ vertical distance from upper tree level to covers, 2) similar

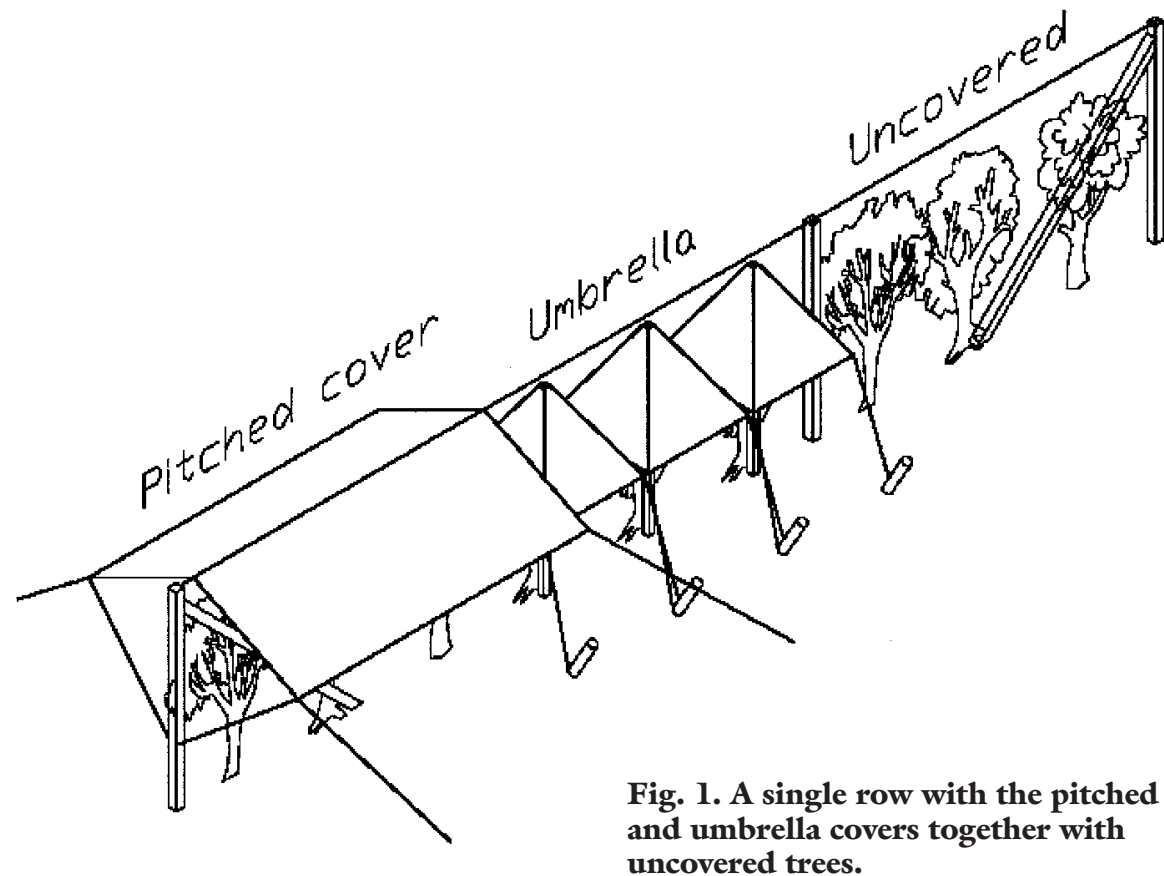

covers, only when rain was forecasted or occurred (rain covering), and 3) umbrella type covers $[0.1 \mathrm{~m}(0.3 \mathrm{ft})]$ vertical distance from tree top to covers. Uncovered trees served as controls. The pitched type covers were cross laminated polyethylene sheets [dimensions $4.5 \times 7 \mathrm{~m}(14.8 \times 23 \mathrm{ft})]$ supported by a wire at top of wooden poles [at $3.5 \mathrm{~m}$ $(11.5 \mathrm{ft})]$ and tied with ropes to trees in the neighboring row (Fig. 1). Technical details were described by Selberg et al. (1995) and Meland and Skjervheim (1998). The umbrella covering system was permanently mounted single tree covers of the same type as above (dimensions $4.5 \times 4.5 \mathrm{~m}$ ) supported by an aluminum pole in the middle of each tree and fastened to plugs in the ground, hence enveloping the upper part of the trees (Fig. 1). The cover consisted of 0.1-mm-thick [4-mil (0.0039-inch)] polyethylene and the light transmittance was about $80 \%$ at 400 to $1100 \mathrm{~nm}$ and $0 \%$ at 300 to $350 \mathrm{~nm}$ [ultraviolet (UV)]. Each cover sheet dimensions was dependent on cover type, either covering one or three trees. The covering period lasted 3 weeks before and throughout the harvest (Table 1).

Climate measurements. Hourly recordings of temperature $\left({ }^{\circ} \mathrm{C}\right)$, relative humidity $(\mathrm{RH})$ and leaf wetness $\left(\mathrm{min} \cdot \mathrm{h}^{-1}\right.$ wet $)$ were provided by a datalogger (CRI0; Campbell Scientific Inc., Logan, Utah) during the 1995 covering period. One temperature and relative humidity sensor ( $\mathrm{MP100}$; Rotronic AG, Bassersdorf, Switzerland) and one leaf wetness sensor (Campbell Scientific) were placed $2 \mathrm{~m}$ high in the tree canopy of all treatments. The distance between sensors and covers was $1.5 \mathrm{~m}(5 \mathrm{ft})$. In addition, wind $\left(\mathrm{m} \cdot \mathrm{s}^{-1}\right)$, temperature and relative humidity were recorded at $2 \mathrm{~m}$ height in the same way in the alleyway as a reference to recordings in the trees, and hourly values of differences between the reference and the research trees were used to minimize the disparity between the sensors. Measurements of relative humidity were used to calculate vapor pressure $(\mathrm{kPa})$. Hourly recordings were divided into three periods representing daytime (0800 to $1900 \mathrm{HR}$ ), dawn and dusk $(0400$ to $0700+2000$ to $2200 \mathrm{HR})$ and night (2300 to $0300 \mathrm{HR}$ ). Daily values of precipitation and global radiation were obtained from the automatic weather station at Ullensvang Research Centre located $200 \mathrm{~m}(656 \mathrm{ft})$ from the research trees.

Fruit Quality measurements. When fruit from uncovered trees reached normal harvest maturity, samples of 150 fruit from each tree were picked. In 1994 these fruit were picked randomly from the whole tree, while the following year 50 fruit were sampled from each of three parts of the tree; the bottom, the middle and the top. Fruit were assessed for external and internal fruit quality. Marketable yield (healthy and undamaged fruit) per tree was harvested and weighed. Number of fruit with cracks, fungal decay and other culls (bird and insect larvae damage) were recorded. 
Table 1. Marketable yield and external quality of sweet cherry fruit from trees covered differently, in 2 years.

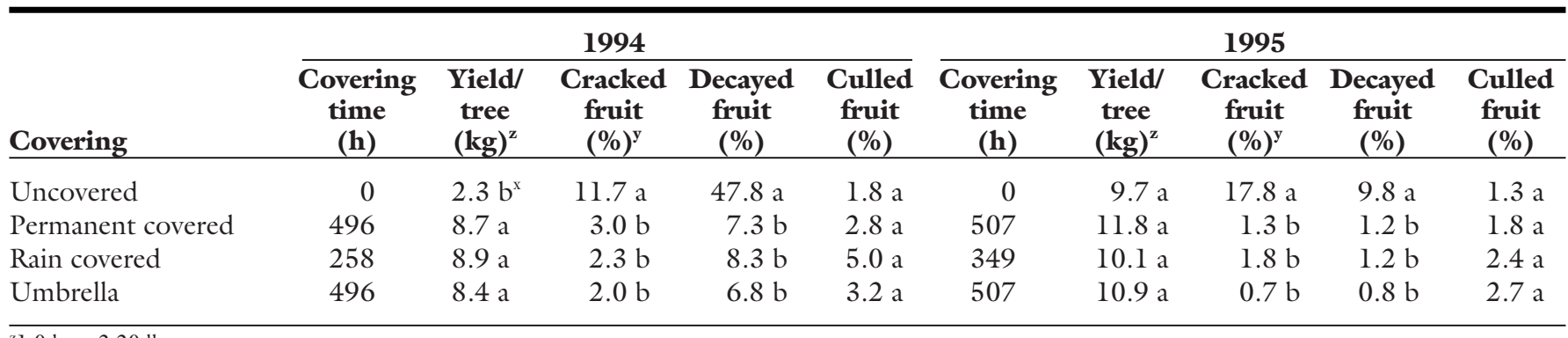

${ }^{\mathrm{z}} 1.0 \mathrm{~kg}=2.20 \mathrm{lb}$.

yIncidence data were arcsin transformed before analysis, values presented are nontransformed means.

${ }^{\mathrm{x}}$ Mean values denoted with different letters are significantly different $(P=0.05)$ according to Student Newman Keuls test.

All fruit with fungal decay were assessed as decayed even if they were cracked or had other culls. Maturity stage was judged on undamaged fruit by rating scores from 1 to 9 in 1994 and 1 to 7 in 1995, where $1=$ light and $9=$ dark red (rated subjectively) and $\mathrm{l}=$ light and 7 = dark red according to Planton (1995), respectively. Fruit weight of healthy fruit was measured. Fruit juice samples were made from 30 healthy fruit and measured for percent soluble solids by an table refractometer (Atago DBX50; Atage, Tokyo, Japan), and then diluted to $5 \%$ and assessed for color with a spectrophotometer at $520 \mathrm{~nm}$ and for titratable acid contents (titration with $0.1 \mathrm{~N}$ sodium hydroxide, $\mathrm{pH}$ 8.10). In 1994 the fruit juice samples were measured for fruit color and titratable acid after freezing, and at harvest in 1995. Firmness was assessed by a penetrometer(PNR 10; Sommer and Runge $\mathrm{KG}$, Berlin, Germany), at three different locations on each of 10 fruit.

All fruit quality observations were analysed statistically by using the GLM procedure of SAS software (SAS Institute, Cary, N.C.). Mean values were separated by Student Newman Keuls method at $P=0.05$. Percentage data were arcsine square transformed before analysis.

\section{Results}

Season climate. Precipitation occurred in $13 \mathrm{~d}$ [138 h, 28\% of total covering time, $43 \mathrm{~mm}$ (1.7 inches)] in 1994 and in $9 \mathrm{~d}[82 \mathrm{~h}, 16 \%$ of total covering time, $66 \mathrm{~mm}$ (2.6 inches)] in 1995 (Fig. 2). Consequently, during the covering periods the amount of global radiation was lower in 1994 than in 1995 . The mean daily global radiation during the covering periods was 12.6 and $14.1 \mathrm{MJ}$ (163.2 and 145.8 $\mathrm{W} \cdot \mathrm{m}^{-2}$ ) per day in 1994 and 1995 , respectively (Fig. 2).
Yield. Covered trees (all methods) had significantly lower cracking incidence $(P=0.026$ and $P=0.0001)$ and disease incidence $(P=0.0001$ and $P$

$=0.0001)$ compared to uncovered trees in 1994 and 1995, respectively (Table 1). No significant differences between the different covering methods were

\section{4}

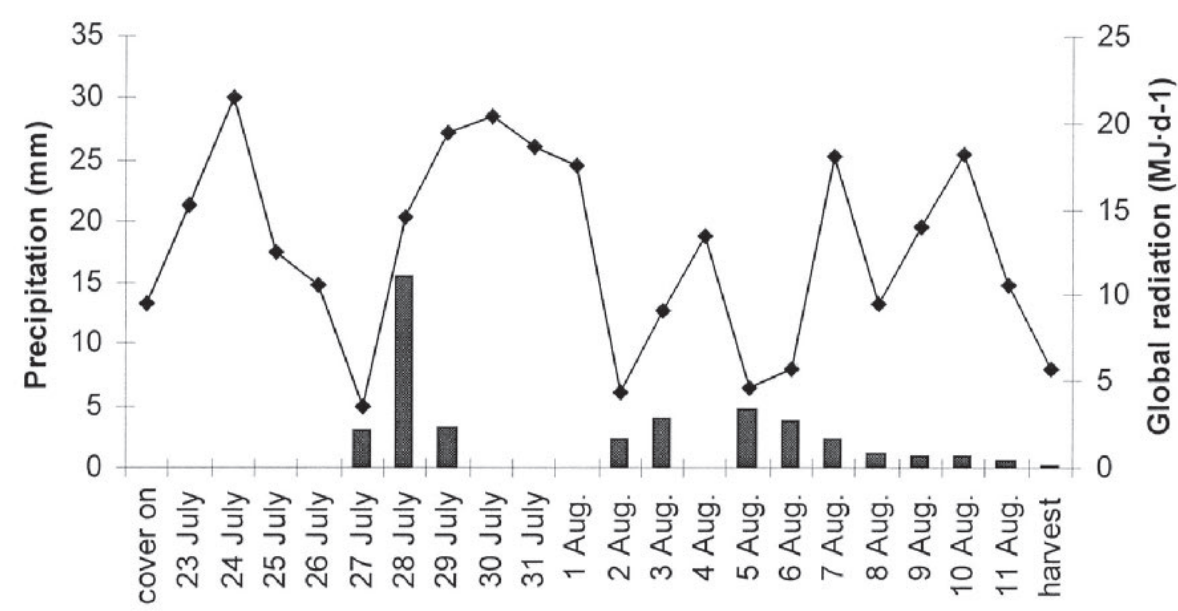

\section{5}

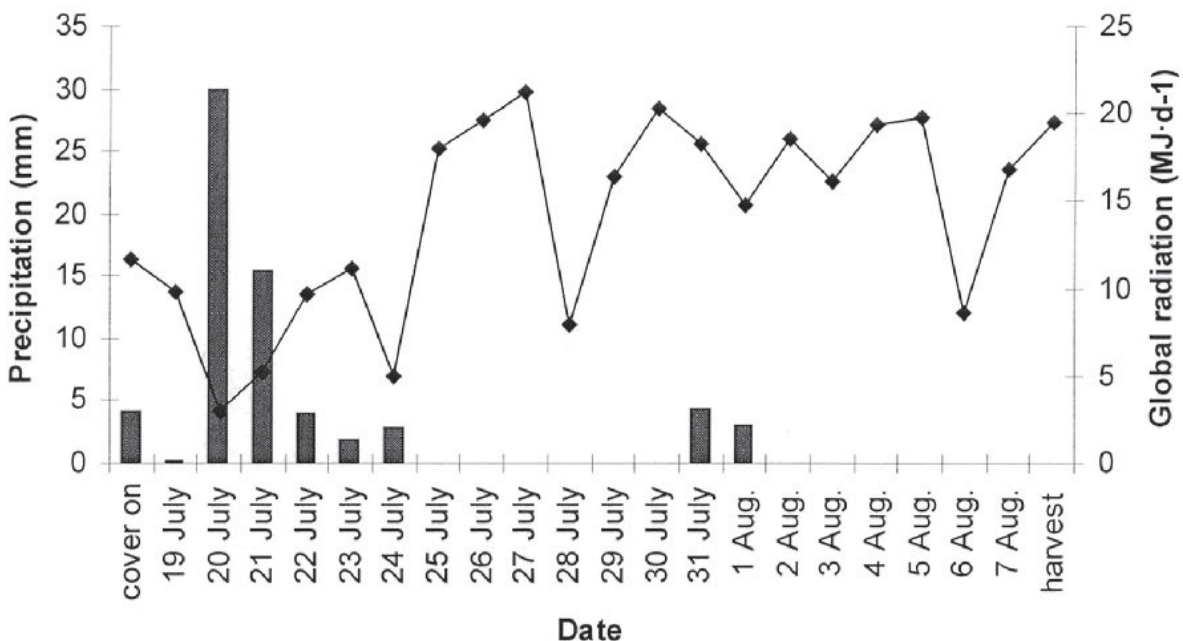

Fig. 2. Daily precipitation (bars) and sum global radiation from covering to harvest, recorded at the meteorological station at Ullensvang Research Centre,

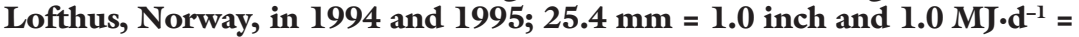
$11.57 \mathrm{~W} \cdot \mathrm{m}^{-2}$. 
Table 2. Effects of different covers on mean vapor pressure (V), mean air temperature (T), and total hours (HR) with leaf wetness $(\mathrm{W})$ recorded in 4-year-old sweet cherry trees during different periods of the day in 1995.

\begin{tabular}{|c|c|c|c|c|c|c|c|c|c|}
\hline \multirow[b]{3}{*}{ Covering } & \multicolumn{9}{|c|}{ Period of day } \\
\hline & \multicolumn{3}{|c|}{ 0800-1900 } & \multicolumn{3}{|c|}{$0400-0700+2000-2200$} & \multicolumn{3}{|c|}{ 2300-0300 } \\
\hline & $\begin{array}{c}\mathrm{V} \\
(\mathbf{k P a})^{z}\end{array}$ & $\begin{array}{c}\mathbf{T} \\
\left({ }^{\circ} \mathbf{C}\right)^{y}\end{array}$ & $\begin{array}{l}\text { W } \\
(\mathbf{h})\end{array}$ & $\begin{array}{c}\mathrm{V} \\
(\mathbf{k P a})\end{array}$ & $\begin{array}{c}\mathbf{T} \\
\left({ }^{\circ} \mathbf{C}\right)\end{array}$ & $\begin{array}{c}\text { W } \\
(\mathbf{h})\end{array}$ & $\begin{array}{c}\mathrm{V} \\
(\mathbf{k P a})\end{array}$ & $\begin{array}{c}\mathbf{T} \\
\left({ }^{\circ} \mathbf{C}\right)\end{array}$ & $\begin{array}{l}\text { W } \\
\text { (h) }\end{array}$ \\
\hline Uncovered & 15.4 & 18.3 & 17.3 & 14.3 & 14.9 & 14.0 & 14.1 & 14.5 & 10.0 \\
\hline Permanent covered & 15.9 & 19.3 & 0.0 & 14.6 & 15.1 & 0.0 & 14.5 & 14.6 & 0.0 \\
\hline Rain covered & 15.9 & 19.3 & 0.3 & 14.5 & 15.1 & 6.5 & 14.3 & 14.8 & 5.4 \\
\hline
\end{tabular}

${ }^{\mathrm{z}} 1.0 \mathrm{kPa}=0.01$ bar.

${ }^{\mathrm{y}} 1.8\left({ }^{\circ} \mathrm{C}\right)+32={ }^{\circ} \mathrm{F}$.

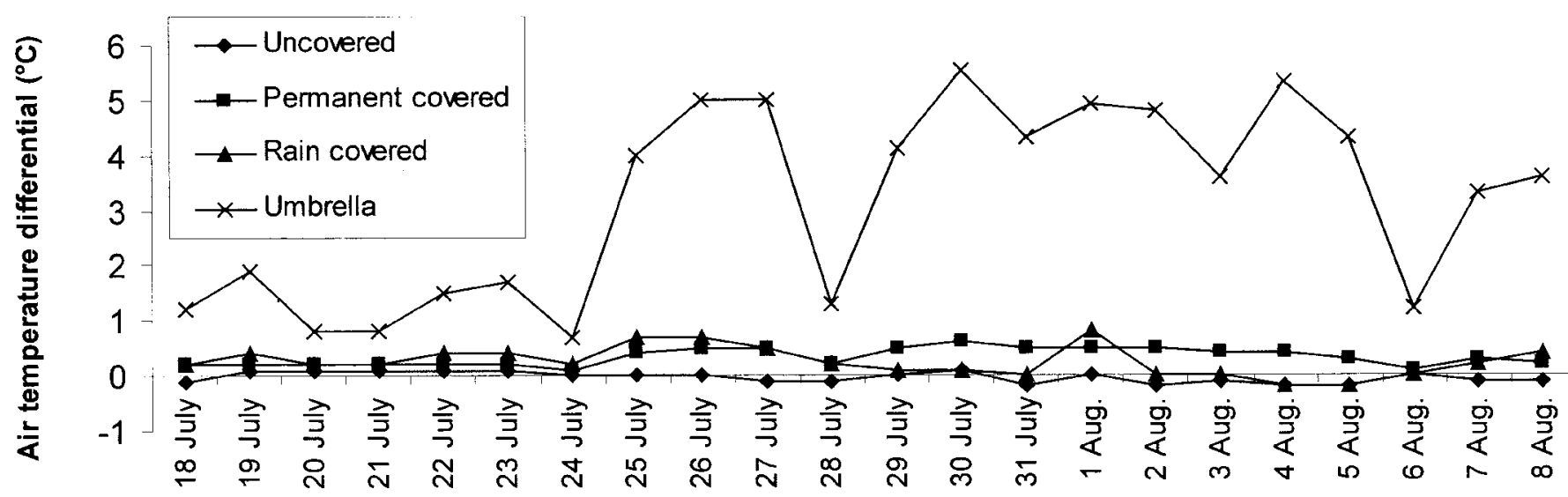

Date

Fig. 3. Mean daily air temperature differential between a reference point at a stand in the alley way, and trees under covers or control in $1995 ; 1.8\left({ }^{\circ} \mathrm{C}\right)+32={ }^{\circ} \mathrm{F}$.

Cloudy

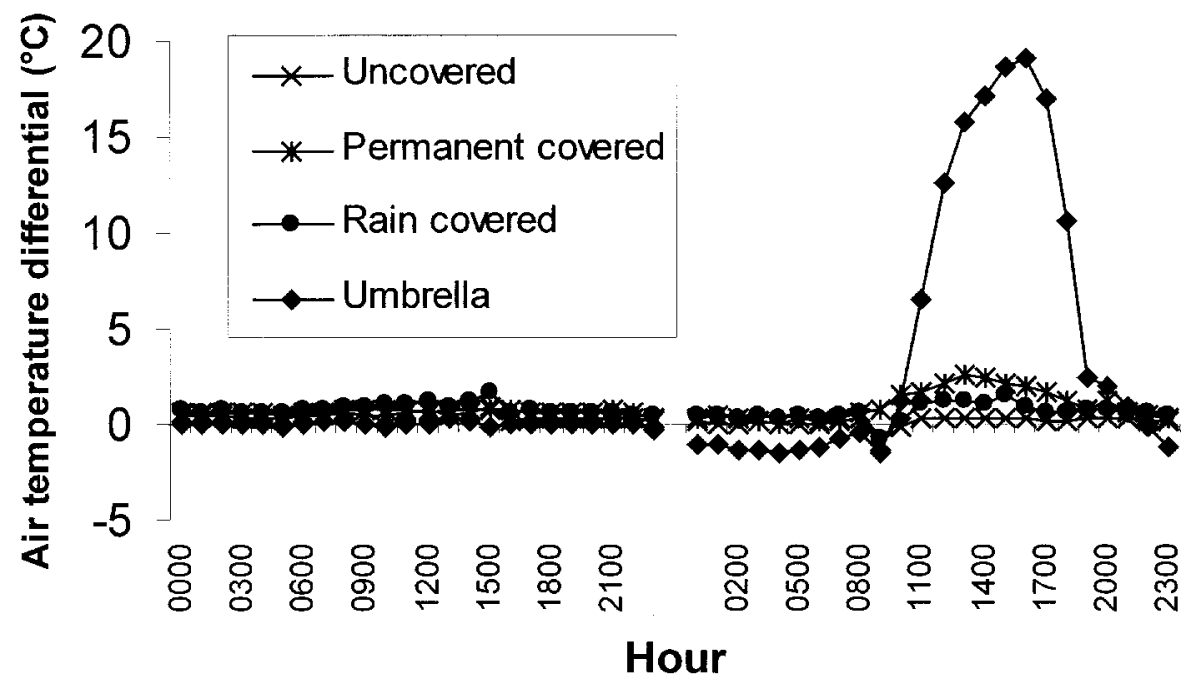

Fig. 4. Hourly air temperature differential between a reference point at a stand in the alley way, and trees under covers or control, during a day with clouds and one with full sunshine in $1995 ; 1.8\left({ }^{\circ} \mathrm{C}\right)+32={ }^{\circ} \mathrm{F}$. obtained (Table 1). Disease incidence was significantly lower in 1995 compared to $1994(P=0.0001)$, while cracking incidence was equal in 1994 and 1995. Predominant diseases in the area are brown rot (Monilinia laxa) and gray mold (Botrytis cinerea) (Børve et al., 2000). Percent fruit with other culls showed no significant differences between covering methods or years. Amount marketable yield per tree was significantly lower on uncovered trees in 1994 but not in 1995 (Table 1).

Microclimate. Umbrella covers caused greater temperature fluctuations in the trees between day and night than the other covering methods, and only small differences were found between covered and uncovered (Table 2). Day to day variations in vapor pressure (data not presented) followed the same pattern as temperature. The differences in temperatures between umbrella covered trees and the reference recordings (Fig. 3) fluctuated from day to day as the level of global radiation (Fig. 2). Large temperature differences between umbrella covered trees and reference recordings were found on days with high global radiation during the day, with only small differences on overcast days (Fig. 4). During the night the temperature was lower in umbrella covered trees 


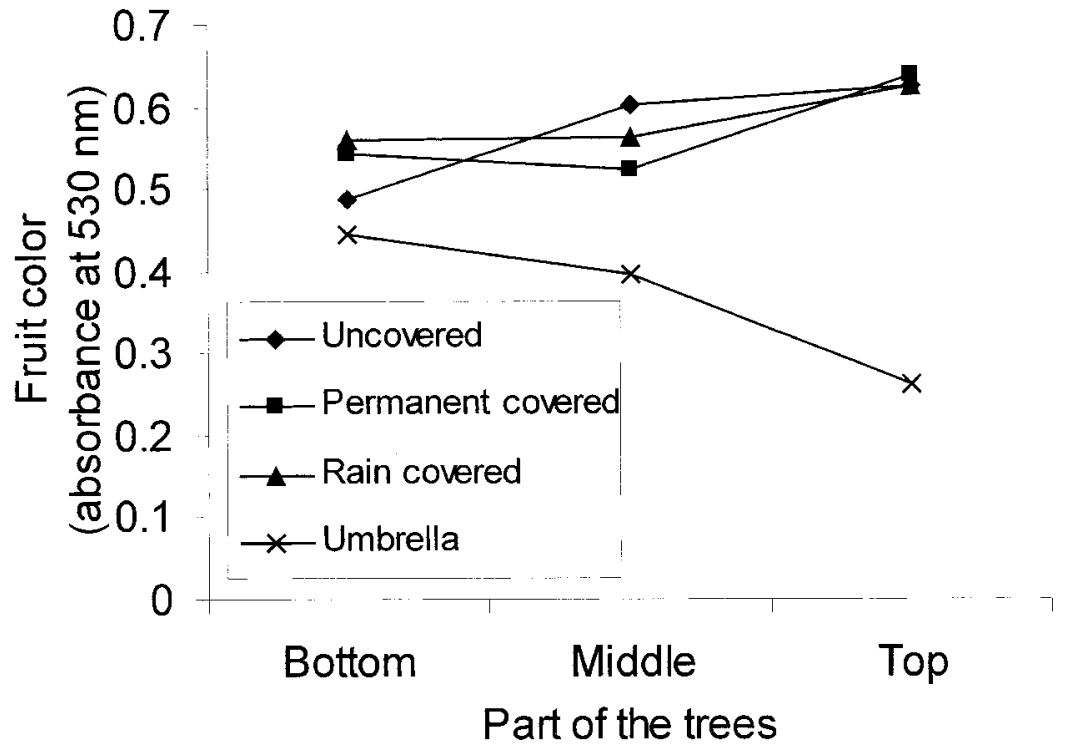

Fig. 5. Color of fruit from different parts of covered and control trees in 1995.

than in trees with other covers (Table 2 ). Vapor pressure was highest during the day in umbrella covered trees compared to all others, and about at the same level as the other trees at night and dawn and dusk. Number of hours with wet leaves was highest in uncovered trees, but only slightly higher than in umbrella covered trees (Table 2). Leaves on uncovered trees were wet longer during the day than those under umbrella covers, while at night the situation was opposite. In the dawn and dusk periods, leaf wetness was equal in umbrella covered and control trees. The differences in leaf wetness between the two pitched cover types were small, but in all periods leaf wetness was lower in permanently covered trees (Table 2 ). Total hours with wet leaves during the total covering period of $507 \mathrm{~h}$ was $4 \mathrm{l}, 0$, 12 , and $35 \mathrm{~h}$ in control, permanently, rain and umbrella covered trees, respectively.

Fruit QUALITY. Fruit from umbrella type covered trees were significantly less ripe than fruit from the other trees in both $1994(P=0.0006)$ and in $1995(P=0.0001)$. In 1995 this also was apparent as lower values of juice color $(P=0.0001)$, soluble solids $(P=$ $0.0006)$ and soluble solids to acid ratio $(P=0.024)$ (Table 3$)$. The other measured quality factors, firmness and fruit weight did not differ among covering methods (data not shown).

When comparing quality parameters of fruit from different positions in the trees, fruit from umbrella type covered trees showed a tendency (not significant) of decreasing color (Fig. 5), soluble solids content and ripeness (data not shown) from bottom to top position. All other covering methods showed an opposite pattern $(P=0.03,0.02$, and 0.02 for ripeness, soluble solids and color on uncovered trees, respectively) or no differences among positions (all other).

\section{Discussion}

All tested covering methods significantly increased marketable yield by reducing the amount of both fruit cracking and fruit decay compared to con- trols. Decreased amount of nonmarketable fruit (not separated in incidence of cracked and decayed) under covers has also been reported from Switzerland (Meli, 1982; Meli et al., 1984; Neidhart, 1980; Riesen et al., 1991; Zbinden, 1988). Reduced fruit decay under covers was also reported from Switzerland (Rüegg and Siegfried, 1993; Rüegg et al., 2000; Schwizer, 2001) and Germany (Balmer, 1998) while a reduced cracking under covers was reported from Norway (Cline et al., 1995) and Washington state (Opperman, 1988a). All covers tested were of the pitched type, so results from umbrella-type covers have not been reported.

Free water is a prerequisite for infection by fungal pathogens that cause fruit decay of sweet cherries. The covers tested were impermeable to water, and hence only condensation under the covers could increase disease risk during the covering period. More wetness was recorded under umbrella cover compared with pitched covers but not more fruit decay. This may be explained partly by the lower ripening stage of the umbrella covered fruit, since sweet cherries become more susceptible to fruit decay as they mature (Northover and Biggs, 1990), and partly by the number of overcast days causing smaller temperature differences between day and night, resulting in subsequently short periods with condensation. However, some hours with wet leaves were recorded at nighttime and at dawn and dusk due to condensation of water under the umbrella cover in this experiment, but the gap between the trees and the cover, together with the slope of the terrain, most likely led to sufficient air flow around the trees that reduced condensation under the pitched covers.

Higher temperature and higher vapor pressure were recorded under umbrella type covers compared to the other covers and control. This may have

Table 3. Quality factors of fruit from trees under different covers, in 2 years.

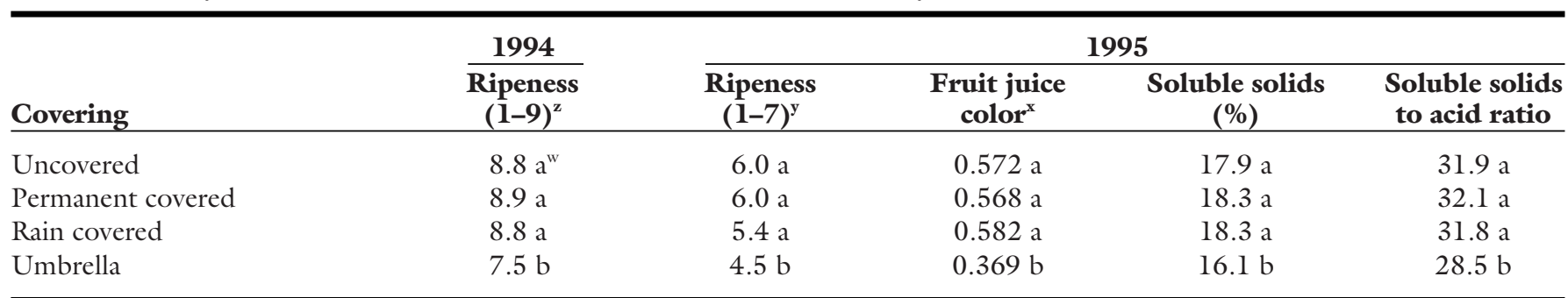

${ }^{z}$ Ripeness 1 to 9 rated subjectively by a scale where $1=$ light and $9=$ dark red

yRipeness judged by a scale ( 1 to 7 ) where $1=$ light and $7=$ dark red (Planton 1995).

${ }^{\mathrm{x}}$ Color measured as absorbance at $520 \mathrm{~nm}$.

${ }^{w}$ Mean values denoted with different letters are significantly different $(P=0.05)$ according to Student Newman Keuls test. 
delayed maturity processes such as color development and accumulation of soluble solids, as reported from Switzerland (Meli et al., 1984; Zbinden, 1988) and Washington state (Opperman, 1988a). Meli et al. (1984) and Opperman (1988b) reported episodes of high temperatures in the top of covered trees. Trought et al. (1994) and Cline and Webster (1994) also recorded higher temperatures under a pitched cover but without any delayed fruit ripening. No delay in maturity of fruit under pitched covers was found in this experiment, most likely because the trees were young and open trained. Similarly, no delay in ripening under covers was reported from Norway (Cline et al., 1995). However, lower level fruit soluble solids under covers were reported from New Zealand (Trought et al., 1994) and when covers enveloped the tree sides in the UK (Cline and Webster, 1994). When using cover sheets only on top of the trees, no effect on soluble solids content of the fruit was recorded (Cline and Webster, 1994) which is in accordance with the present results obtained under the pitched and umbrella covers.

Other covering trials have reported temperature and fruit quality effects when using a pitched cover (Cline and Webster, 1994; Meli et al., 1984; Opperman, 1988a; Opperman, 1988b; Trought et al., 1994; Zbinden, 1988). Only small differences in both fruit quality and microclimate were recorded in the present experiments between the pitched covering methods and controls. A reason for this may have been the high number of days with rain and cloudy weather during the ripening period, although temperature differences between the umbrella covered trees and the reference point were only distinct on sunny days. Such days were more frequent in 1995 than in 1994, and consequently the effect of umbrella covers on fruit quality and microclimate were more distinct in 1995. Similar effects may be expected even under pitched cover in orchards on horizontal or about horizontal ground, where the covers will prevent vertical air movement more than on sloping ground, as in the present experiment.

The slightly negative effect of covering on fruit quality was insignificant compared to the increased amount of marketable fruit, even in umbrella covered trees. Based on experiences both from this experiment and from discus- sions with growers, the authors do not recommend the use of umbrella covering due to its high labor costs. Delayed ripening due to covering may be beneficial in many production regions to extend the marketing season. Removing covers in dry weather is probably more beneficial in drier climates than in the fruit growing regions of Norway. Similarly, beneficial effects of removing covers are more likely in orchards with densely trained trees, planted on horizontal ground.

\section{Conclusions}

Three different rain protective covering methods increased the amount of marketable sweet cherry fruit at about the same extent. Umbrella covers delayed ripening and reduced fruit quality when using the same harvest date, while the other two methods showed no negative effect on fruit quality compared to fruit from uncovered trees. Umbrella covered trees had higher air temperature and greater vapor pressure than the pitched covered trees. These differences were most distinct in sunny conditions. The beneficial effects of covers was greater for reducing fruit decay than for impacting other quality factors.

\section{Literature cited}

Balmer, M. 1998. Preliminary results on planting densities and rain covering for sweet cherry on dwarfing rootstock. Acta Hort. 468:433-439.

Børve, J. and M. Meland. 1998a. Rain cover protection against cracking of sweet cherries. I. The effects on marketable yield. Acta Hort. 468:449-453.

Børve, J. and M. Meland. 1998b. Rain cover protection against cracking of sweet cherries. II. The effects on fruit ripening. Acta Hort. 468:455458 .

Børve, J., L. Sekse, and A. Stensvand. 2000. Cuticular fractures promote postharvest fruit rot in sweet cherries. Plant Dis. 84:1180-1184.

Cline, J. and A.D. Webster. 1994. Cherries under wraps. Grower 121(24):16-17.

Cline, J.A., M. Meland, L. Sekse, and A.D. Webster. 1995. Rain-induced fruit cracking of sweet cherries: II Influence of rain covers and rootstocks on cracking and fruit quality. Acta Agr. Scand. 45:224-230.

Meland, M. and K. Skjervheim. 1998. Rain cover protection against cracking for sweet cherry orchards. Acta Hort. 468:441-447.

Meli,T. 1982.Abdecken von Süsskirschen-hecken mit Polyätylenfolien. III Betriebs- und arbeitswirtschaftliche Aspekte. Schweizerische Zeitschrift Obst Weinbau 118:812-821.

Meli, T, W. Riesen, and A. Widmer. 1984. Protection of sweet cherry hedgerows with polyeth- ylene films. Acta Hort. 155:463-467.

Neidhart, E. 1980. Folienüberdachung bei Tafelkirschen. Erwerbsobstbau 22:120-122.

Northover, J. and A.R. Biggs. 1990. Susceptibility of immature and mature sweet and sour cherries to Monilinia fructicola. Plant Dis. 74:280-284.

Opperman, D. 1988a. Cherry umbrella tried for protection against frost, wind, and rain. Part 1. Fruit quality results. Good Fruit Grower 39(4):2630 .

Opperman, D. 1988b. Cherry umbrella tried for protection against frost, wind, and rain. Part 2. Meteorological, pollinization and other cultural factors. Good Fruit Grower 39(5):22-25.

Planton, G. 1995. Cerise: un code coleur pour améliorer la qualité à la rècolte. [Cherries: A colour code to improve crop quality.] Centre Technique Interprofessionnel des Fruit et Legumes. Paris, France. Infos No. 112. 38-41.

Riesen, W., T. Meli, W.Zbinden, and A. Widmer. 1991. Regendach Für Tafelkirschen. Schweizerische Zeitschrift Obst Weinbau 127:360-372.

Rüegg, J. and W. Siegfried. 1993. Intigrierte Obstproduktion: Neues zur Blüten- und FruchtMonilia. Schweizerische Zeitschrift Obst Weinbau 129:620-624.

Rüegg, J., H. Höhn, and T. Schwizer. 2000. Regenschutzfolien in der biologischen und integrierten Tafelkirschenproduktion. Teil I Einfluss auf Krankheiten, Schädlinge, Mikroklima und Ertrag. Schweizerische Zeitschrift Obst Weinbau 136:64-67.

Schwizer, T. 2001. Witterungschutz bei Süsskirschen. Schweizerische Zeitschrift Obst Weinbau 137:326-329.

Selberg, A., K. Skjervheim, M. Meland, J. Ulgenes, and O. Hovland. 1995. Dekkesystem for søtkirsebær. Byggjerettleiing. [Covering systems for sweet cherries. Building instructions.] Faginfo nr. 7 1995. Infosenteret Forskingsparken i Ås AS, Ås, Norway.

Trought, M, R. Edwards, S. Lang, and A. Naylor. 1994. Influence of covers on environment and fruit composition of sweet cherries, p. 33-34. In: Proc. Intl. Conf. Cracking in Cherries, Michigan, USA, 4-5 Feb. 1994. Dept. Hort., Mich. State Univ., East Lansing.

Vittrup Christensen, J. 1996. Rain-induced cracking of sweet cherries: Its causes and prevention, p. 297-327. In A.D. Webster and N.E. Looney (eds.). Cherries: Crop physiology, production and uses. CAB Intl., Oxon, U.K.

Zbinden, W. 1988. Regenshutz für KirschenGesunde Tafelfrüchte. Schweizerische Zeitschrift Obst Weinbau 124:364-365.

Zilkah, S., I. David, Y. Yeselson, S. Moreshet, E.E. Gussakovsky, K. Ratner, and Y. Shahak. 1997. Advanced maturity and improved size of 'Burlat' and 'Chinook' sweet cherry fruit under UV-absorbing plastic, p. 320-325. In: S. BenYehoshua (ed.). International congress for plastics in agriculture. CIPA proceedings. Laser Pages Publ. Ltd. Jerusalem, Israel. 